(C) T.M. Popova

УДК 615.07:612.64: 504.054

DOI https://doi.org/10.31718/mep.2018.22.5-6.04

\title{
EVALUATION OF GROWTH AND DEVELOPMENT OF RAT PUPS, PRENATALLY EXPOSED TO LAPROL-604
}

\section{T.M. Popova}

Kharkiv national medical university, Kharkiv, Ukraine

The article introduces findings of the study on surfactant-induced effects on the growth and maturation of rat pups, prenatally exposed to Laprol-604. The adverse influence of Laprol-604 exposure on rat fetuses was identified in the immediate postnatal period (0-3 days) and later. Laprol-604 induced neonatal mortality within the period of three days, reduced litter size, resulted in low-birth-weight of progeny and a decrease in body weight gain in rat pups. Somatic growth retardation produced by Laprol-604 persisted during postnatal period and was accompanied by a delay in integumental morphogenesis of rat pups. Closer examination revealed an impact of Laprol-604 on delayed opening of the external auditory canal, resulting in an altered sequence of craniofacial development, such as the time of eyelid opening, incisor eruption. Maternal Laprol-604 exposure adversely affected the release and erection of the pinna. In summary, Laprol604 had dosage-dependent developmental toxicity effect on progeny of female rats exposed to Laprol-604 during gestational period.

Key words: Laprol-604, surfactant, reproductive toxicity, developmental toxicity, gestation day, postnatal day.

У статті представлені результати експерименту з вивчення постнатального онтогенезу щурів, які в антенатальному періоді розвитку піддавалися впливу Лапролом-604. Поверхнево-активні речовини та продукти їх розпаду негативно впливають на різні системи середовища $[8,10,11]$. 3 наукової літератури відома токсична дія поверхнево-активних речовин на живі організми $[1,2,11]$. Найбільш інтенсивно з токсикологічної точки зору вивчаються неіонні поверхнево-активні речовини $[6,9]$. Резултати досліджень біологічної дії поверхнево-активних речовин свідчать про структурно-метаболічні порушення, а також про можливість віддалених наслідків, таких як прискорення імунодефіциту, мутагенез, інгібування чоловічої фертильності у щурів, несприятливі репродуктивні ефекти $[7,10,11]$. Тим не менш, результати досліджень репродуктивноі дії поверхнево-активних речовин $\epsilon$ малочисельними. Оцінити вплив Лапрола-604 на постнатальний розвиток щурів, що піддавалися його пренатального впливу стало метою дослідження. Сто вагітних щурів лінії Wistar (маса тіла, $210 \pm 30$ г на початку дослідження) рандомізовано розділені на чотири групи ( по 25 самиць у кожній групі). Самицям 1-ої, 2-ої та 3-ої груп, щоденно, внутрішньошлунково, з 2-го по 21-й гестаційні дні, вводили Лапрол-604 в дозах 0,125; 1,25 та 12,5 мг/кг, відповідно. Четверту (контрольну) групу склали інтактні самиці та їхні нащадки. Пренатальна дія досліджуваного поліолу призвела до статистично значимого зменшення кількості новонароджених щурів у 3-й, 2-й та 1-й експериментальних групах, у порівнянні з контролем. Народитивні щурята 3-ої групи померли протягом перших 48 годин після народження. 50\% щурят 2-ої групи померли протягом перших десяти діб з моменту народження, інші 50\% - вижили та досягли статевої зрілості, проте, демонстрували затримку у відлипанні вушної раковини, відкритті очей на 2 доби в порівнянні з контролем. Виживання щурят 1-ої групи становило 80\% у порівнянні з контролем. Нащадки були активними впродовж постнатального розвитку та досягли статевої зрілості. Проте, серед них зареєстровано тенденцію відставання у постнатальному онтогенезі в порівнянні з контролем.

Ключові слова: Лапрол-604, поверхнево-активна речовина, репродуктивна токсичність, токсичний вплив на постнатальний розвиток, гестаційний день, постнатальний день.

\section{Introduction}

High production volumes and widespread use of surfactants have been an environmental concern since the early 1960s. The presence of surfactants and their biodegradation products in different environmental compartments can invoke a negative effect on the biota [8, $10,11]$.The toxicity of surfactants on living organisms has been summarized in scientific literature $[1,2,11]$. Nevertheless, information on reproductive effects of surfactants is still insufficient and needs to be expanded to avoid unexpected adverse effects on future generations of people and the environment.

Nonionic surfactants have been most intensively studied from a toxicological standpoint [6, 9]. Multiple reports, in a variety of animal models, present a concerning pic- ture of the surfactants' potential to contribute to negative health effects, including developmental toxicity, immunological suppression in neonatal mortality [5]. Investigations show that biological action of non-ionic surfactants are characterized by numerous structural metabolic disorders, as well as possibility to condition remote consequences, such as acceleration of immune deficiency, mutagenesis, inhibition of male fertility in rats, adverse reproductive effects and so on [7, 10,11].

Laprol-604 is a nonionic surfactant, which has been investigated with toxicological aim. Despite this, the impact of Laprol-604 on reproductive system is still unknown.

The aim of the present study was to assess the impact of Laprol-604 on the development of rat pups prenatally exposed to this surfactant.

* To cite this English version T.M. Popova. Evaluation of growth and development of rat pups, prenatally exposed to laprol-604. // Problemy ekologii ta medytsyny. - 2018. - Vol 22, № 5-6. - P. 19-21. 


\section{Materials and methods}

Laprol-604 was provided by Science and Production Laprol-604 was reported to be $96 \%$ pure by the supplier. For all the studies, Laprol-604 was diluted in deionized water and prepared fresh daily.

According to biologic characteristic of Wistar rats, placenta is considerably more porous. This property may increase the chance of fetal exposure to an administered test material.

One hundred pregnant Wistar rats (body weight, $210 \pm 30$ $\mathrm{g}$ at the beginning of the study) bred within a 4-h period in the afternoon and overnight. Those animals with spermatozoa in vaginal smear were considered to be at gestation day (GD) 0 . They were randomly divided into four groups (25 animals in each group). Laprol-604 was administered to pregnant dams once daily by gavage at doses of $0.125 ; 1.25$ and $12.5 \mathrm{mg} / \mathrm{kg}$, respectively in the $1^{\text {st. }} ; 2^{\text {nd }}$ and $3^{\text {rd }}$ group from GD 2 until GD 21. The $4^{\text {th }}$ group (controls) consisted of 25 intact animals without Laprol-604 administration. The pregnant dams were kept individually in polypropylene cages with heat-treated pine shavings for bedding and tap water ad libitum. Pelleted diets were presented to the rats in wide mouthed jars with lids. Animal facilities were controlled by temperature $\left(20-22^{\circ} \mathrm{C}\right)$ and relative humidity (50-60\%) and kept under a 12-hr light/12-hr dark cycle.

All the procedures were performed in Kharkiv Medical Academy of Postgraduate Education, according to Ukrainian and International guidelines for the use of animals in research [3, 4]. Pregnant rats and their pups were routinely monitored during the study to assess their general health and the effect of Laprol-604 administration.

Pregnant rats were clinically observed twice every day. Pregnant rats were monitored at hourly intervals, within 22 GD and later. The study involved evaluation of the time of parturition for each animal, number of live pups and their condition. All the live pups were daily counted, tabulated and weighed on $0,2,3,7,10,13,16,19,22,28$ and $35^{\text {th }}$ postnatal day (PD). Pinna detachment and ear-canal opening, eye opening, incisor eruption, air drop righting reflex, auditory response and motor activity/emotionality, and passive avoidance were taken into account (four males and four females from each litter). The loss of neonates was within $2^{\text {nd }}$ and $3^{\text {rd }}$ groups.

On $16^{\text {th }}$ postnatal day, 60 pups of both genders were randomly chosen from several litters (twenty pups from the Joint Stock Company "Sintez PAV" (Shebekino, Russian).

$1^{\text {st }}, 2^{\text {nd }}$ and control groups) were weighed and sacrificed by decapitation. Liver, kidney and brain samples were removed, weighed and immediately frozen on dry ice and stored at $-80^{\circ} \mathrm{C}$ for investigation.

All surviving young rats were weaned on the $22^{\text {nd }} P D$ and separated by gender. The age at which the rat pups reached puberty was determined by tracking vaginal opening in females beginning on PD 30 and preputial separation in males beginning on PD 40 .

Statistical analysis of the data was performed using GraphPad Prism 5. Student's t-test was used to detect differences between independent groups of normally distributed variables; difference between groups was considered statistically significant at $p<0.05$.

\section{Results and discussions}

Laprol-604 administration decreased statistically significant litter size in the $3^{\text {rd }}$ group $(5.48 \pm 0.21), 2^{\text {nd }}(7.07 \pm 0.15)$ and $1^{\text {st }}(8.20 \pm 0.12)$ groups compared with controls $(9.31 \pm 0.23)(p<0.01)$. Body weight of pups in the $12.5 \mathrm{mg} / \mathrm{kg}$ dosage in the $3^{\text {rd }}$ group significantly stunted behind control pups. In addition, all of them were pallid, inactive, became moribund and died within the first 48 hours after birth. Approximately $50 \%$ of the pups born from mothers ( $2^{\text {nd }}$ group) who were daily administered $1.25 \mathrm{mg} / \mathrm{kg}$ died during the first 10 days after birth [7]. Other $50 \%$ of these animals survived and reached puberty. However, survived offspring showed delays in growth and opening of the eyes. The pups opened their eyes on the $14^{\text {th }}$ postnatal day.

Postnatal gain in mean body weight was reduced in rat pups born from mothers who were administered Laprol-604 and these data reported [7].

According to the aim of the trial, all litters and their pups were daily examined. Prenatal administration of Laprol-604 produced the trend toward reduction in weight gain of rat pups in the $1^{\text {st }}$ group. Statistically significant deceleration of body weight gain was observed in offspring of the $2^{\text {nd }}$ and $3^{\text {rd }}$ groups. The following data were obtained on the $16^{\text {th }}$ postnatal day at the time of sacrifice: (controls: body weight $32.6 \pm 0.8 \mathrm{~g}$, liver $0.915 \pm 0.02 \mathrm{~g}$, kidney $0.346 \pm 0.08 \mathrm{~g}$, brain $1.135 \pm 0.02 \mathrm{~g} ; 1^{\text {st }}$ group: body weight $31.3 \pm 0.7 \mathrm{~g}$, liver $0.892 \pm 0.03 \mathrm{~g}$, kidney $0.293 \pm 0.09 \mathrm{~g}$, brain $1.095 \pm 0.02 \mathrm{~g} ; 2^{\text {nd }}$ group: body weight $23.5 \pm 0.1 \mathrm{~g}$, liver $0.96 \pm 0.02 \mathrm{~g}$, kidney $0.264 \pm 0.07 \mathrm{~g}$, brain $1.023 \pm 0.06 \mathrm{~g}$ ). Body weight, absolute and relative liver, kidney and brain weights of rat pups on the $16^{\text {th }}$ postnatal day are illustrated in Table 1.

Table 1

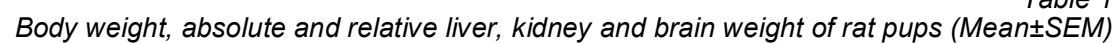

\begin{tabular}{|c|c|c|c|}
\hline \multirow{3}{*}{ Postnatal day } & \multicolumn{3}{|c|}{ Groups of animals } \\
\hline & $\begin{array}{l}\text { Control group } \\
(n=20)\end{array}$ & $\begin{array}{l}\text { First group } 0.125 \mathrm{mg} / \mathrm{kg} \\
(\mathrm{n}=20)\end{array}$ & $\begin{array}{l}\text { Second group } 1.25 \mathrm{mg} / \mathrm{kg} \\
(\mathrm{n}=20)\end{array}$ \\
\hline & \multicolumn{3}{|c|}{ Body weight (g) } \\
\hline 16 & $32.2 \pm 0.8$ & $31.3 \pm 0.7$ & $23.5 \pm 0.1^{*}$ \\
\hline \multirow{4}{*}{16} & \multicolumn{3}{|c|}{ Liver weight (g) } \\
\hline & $0.915 \pm 0.02$ & $0.892 \pm 0.03$ & $0.96 \pm 0.02$ \\
\hline & \multicolumn{3}{|c|}{ Liver/body weight (\%) } \\
\hline & $2.84 \pm 0.02$ & $2.85 \pm 0.06$ & $4.09 \pm 0.03^{*}$ \\
\hline \multirow{4}{*}{16} & \multicolumn{3}{|c|}{ Kidney weight (g) } \\
\hline & $0.346 \pm 0.08$ & $0.293 \pm 0.09$ & $0.264 \pm 0.07^{*}$ \\
\hline & \multicolumn{3}{|c|}{ Kidney/body weight (\%) } \\
\hline & $1.07 \pm 0.06$ & $0.94 \pm 0.06$ & $1.12 \pm 0.04$ \\
\hline \multirow{4}{*}{16} & \multicolumn{3}{|c|}{ Brain weight (g) } \\
\hline & $1.135 \pm 0.02$ & $1.095 \pm 0.02$ & $1.023 \pm 0.06^{*}$ \\
\hline & \multicolumn{3}{|c|}{ Brain /body weight (\%) } \\
\hline & $3.53 \pm 0.09$ & $3.49 \pm 0.08$ & $4.35 \pm 0.07$ \\
\hline
\end{tabular}

Note. * Significant differences $(p<0.05)$ from control values 
No significant differences were registered between data of the $1^{\text {st }}$ and control groups. The data of rat pups of the $2^{\text {nd }}$ group show a progressive retardation of weightgain within the first 2 weeks of their life.

The study also implied evaluation of integumental morphogenesis. Prenatal exposure of rats to Laprol-604 resulted in delayed release and erection of the pinna. Normal epithelial detachment of the pinna occurred in controls 48-72 hours after birth followed by gradual attainment of upright pinna the next day. Prenatal Laprol exposure of pups showed retarded release of the epithelial edge and 48-hours delay in unfolding and erection of the pinna.
By postnatal day 8 , sculpting of the external ear was noticeably poorer in animals of the 2 nd group compared to the 1 st group or controls. In addition, other distinguishing features were present, such as accelerated formation of the oral vestibule, malformation of the vibrissae, and impending eruption of the lower incisors. On the other hand, the lower administered dose of Laprol-604 led to a blunted response relatively similar in appearance to controls.

Subsequent observation revealed that in rat pups of the $2^{\text {nd }}$ group the mean time of the external auditory canal opening was delayed by 72 hours (Table 2).

Effect of Laprol-604 administration on the timing of integument during craniofacial development in rat pups

\begin{tabular}{|c|c|c|}
\hline \multicolumn{3}{|c|}{ Groups of animals } \\
\hline $\begin{array}{c}\text { Control group } \\
(\mathrm{n}=25)\end{array}$ & $\begin{array}{c}\text { First group } 0.125 \mathrm{mg} / \mathrm{kg} \\
(\mathrm{n}=25)\end{array}$ & $\begin{array}{c}\text { Second group } 1.25 \mathrm{mg} / \mathrm{kg} \\
(\mathrm{n}=25)\end{array}$ \\
\hline & Incisor eruption (postnatal day) & $13.5 \pm 0.1$ \\
\hline $9.5 \pm 0.1$ & $10.6 \pm 0.4$ & $15.5 \pm 0.1^{*}$ \\
\hline & Ear canal opening (postnatal day) \\
\hline & $14.7 \pm 0.1$ & $15.41 \pm 0,3^{*}$ \\
\hline $13.2 \pm 0.1$ & Vision (postnatal day) & $14.9 \pm 0.2$ \\
\hline
\end{tabular}

Note. * Significant differences $(p<0.05)$ from control values

In addition, mean eyelid opening was slowed down by 96 hours. Laprol-604 treatment in $0.125 \mathrm{mg} / \mathrm{kg}$ dose had no effect on time of eyelid opening (controls $13.8 \pm 0.2$ days, $1^{\text {st }}$ group $14.9 \pm 0.2$ days). In the present study the time points were chosen because they coincide with a period of rapid organogenesis in the rats, particularly of the liver [9]. The $1.25 \mathrm{mg} / \mathrm{kg}$ dose of Laprol-604 produced significant reduction at both ages in body weight, snoutanus length, and liver, brain ratios $(p<0.05)$. Mean body weight and length in 19-day-old rat pups were as follows: control, $39.2 \pm 0.9 \mathrm{~g}$ and $12.1 \pm 0.2 \mathrm{~cm} ; 2^{\text {nd }}$ group $30.1 \pm 0.7$ $g$ and $8.2 \pm 0.2 \mathrm{~cm}(p<0.01)$.

The present results demonstrate that prenatal period constitutes a critical time for both growth retardation and differential effects of Laprol-604. Thus, a lower total dose of Laprol-604 has less impact on reduction of body weight and deceleration of eyelid opening than a larger dose of this surfactant given to pregnant rats within 20 gestational days.

In rats, the normal sequence of topological signs and their associated functions are: 1) incisor eruption, $10^{\text {th }}$ postnatal day; 2) ear canal opening, $12-13^{\text {th }}$ days; 3 ) vision, 13- $14^{\text {th }}$ day; 4) vaginal opening, $34-36^{\text {th }}$ day. The study showed a delayed release of the pinna in rat pups exposed to Laprol-604. Closer examination revealed an effect of Laprol-604 on a delay in external auditory canal opening, resulting in an altered sequence of craniofacial development. This finding indicated that Laprol-604 could retard some developmental signs. In rodents, the present findings demonstrate that Laprol-604 administration markedly retard external ear canal opening, the time of eyelid opening and incisor eruption.

\section{Conclusions}

1. Maternal Laprol-604 exposure during gestation induced neonatal mortality, reduced litter size, resulted in low birth weight of progeny and deceleration of body weight gain in rat pups.

2. The present study demonstrated an adverse effect of maternal Laprol-604 exposure on the release and erection of the pinna, delayed the time of external auditory canal opening and the mean eyelid opening.
3. The study showed dosage dependency of Laprol-604 on developmental toxicity effect on progeny of female rats exposed to Laprol-604 during gestational period.

\section{References}

1. Bagmut I.Y. The influence of sub-toxic dose xenobiotic on immune response of experimental animals / I.Y.Bagmut, T.M. Popova, A.V. Titkova et al. // J of Education, Health and Sport. - 2016. -Vol. 6(11). - P. 629-639.

2. Bagmut I.U. Evaluation of subtoxic influence of phosphorus organic subtances on the male rat reproductive function during the subacute experiment/ Bagmut I.U., Zharova NV, Zhukov V.I., Tyupka T.I., Popova T.M. // Odessa Medical Journal. - 2016. -Vol. 6 (158). - P. 5-9.

3. Council of Europe [France]. European convention for the protection of vertebrate animals used for experimental and other scientific purposes. Strasbourg,18.III.1986, http://conventions.coe.int/treaty/en/Treaties/Word/123.doc

4. EPA (US Environmental Protection Agency) (1991) Guidelines for Developmental Toxicity Risk Assessment. Risk Assessment forum, US Environmental Protection Agency, Washington/DC. EPA/600/FR-91-001

5. Grasty R.C. (2003) Prenatal window of susceptibility to perfluorooctane sulfonate-induced neonatal mortality in the Sprague-Dawley rat/ Grasty R.C., Grey B.E., Lau C.S. et al // Birth Defect Res . - 2003. -Vol. 68. - P.465-471.

6. Lara-Martin P.A. Sources, transport and reactivity of anionic and non-ionic surfactants in several aquatic ecosystems in SW Spain: a comparative study/ Lara-Martin PA, Gomez-Parra A, and Gonzalez-Mazo E // Environmental Pollution . - 2008. -Vol. 156 (1). - P.36-45.

7. Popova T.M. The reproductive influence of Laprol-604 on wistar rats/ Popova T.M., Zharova NV, Kolesnik I.L. et al // Problems of environment and medicine . - 2015. -Vol. 19 (5/6). - P. 11-16

8. Popova T.M. The typical pathochemical reactions of the damaging impact of detergents as sources of radiotoxins / Popova T.M., Zharova NV, Kolesnik I.L. et al // Problems of environment and medicine . - 2015. -Vol. 19 (5/6). - P. 11-16.

9. Ramesh C Gupta (2011) Reproductive and Developmental Toxicology. Academic press ELSEVIER: 1223

10. Zhukov VI (2000) Environmentally-hygienically description of superficially-active substances as contaminants of reservoirs. Kharkov Tornado:180 [in Russian].

11. Zhukov V., Telegin V., Zaytseva O. et all, Toxicologic and hygienic haracteristics of P-373-2-20; P-5003-AC; P-2942-35 polyols an prognosis of their potential danger to environment: Science Research, 2013, 1(2): P. 31-34.

Матеріал надійшов до редакції 23.11.2018 p. 